Ralph Hattox: [Princeton U]

Alan Makovsky: [Princeton U] James Yarrison: [Princeton U]

Muhs in Yusuf:

[Princeton $U$ ]

Marcia Hermansen:

[U of Chicago]

Bruce Masters:

[U of Chicago]

Michael Sells:

[U of Chicago]

Audrey Altstadt:

[U of Chicago]

Palmira Brummett:

[U of Chicago]

Stephen Caton:

[U of Chicago]

James Broderick:

[U of Chicago]

Carol Delaney:

[U of Chicago]

Antony Greenwood:

[U of Chicago]

Valerie Hoffman:

[U of Chicago]

Kathleen Hatch:

[U of Chicago]

Marcie Patton:

[ $U$ of Chicago]

Phi] ip Remler:

[U of Chicago]

Daniel Goffman:

[U of Chicago]

Yeshayahu Har-EI:

[U of Chicago]

Sharon Hutchinson: Towards a Restudy of the Nuer of Southern Sudan:

[U of Chicago] 1930-1980.

Douglas Streusand: From Isfahan to Agrah: The Migration of Members of

[U of Chicago] the Safavi Political and Cultural Elite to

Mughal India.

Lynda Clarke-Ayoub:

[U of Toronto]

Abbas Bafakih:

[U of Utah]

Wael Hallaq:

[U/Washington]

Coffee Houses and Urban Society in the ottoman Lands in the 15th and 16 th Centuries.

The Sinai Border Crisis, 1892-1906.

Force as an Instrument of Policy: European Military Incursions into the Maghrib, 1000-1355.

The Arab College in Jerusalem.

Religious Thought of Shah Wal i Allah Dihlavi (1702-1763).

The Merchants of Aleppo, 1630-1730: The Commercial Organization and Practices of an 0ttoman-Arab City.

Ibn Arabi and the Plotinian Tradition: A Study of Metaphor and the Tradition of Mystical Discourse.

The Interaction Between the Muslim-Turkic Community in Baku and Ottoman Turkey from the 1870 s to World War I.

The Incorporation of the Zu'l-Kadr Territories into the Ottoman State.

Reformalization of the Concept of Diglossia in Light of Yemenite Arabic Poetry.

Medieval Arabic Dialectology and the Lahn al${ }^{C}$ Armah Literature.

The Process of Parenthood in Turkey.

The Provisioning of Istanbul in the 17 th and 18 th Centuries.

The Corollaries Between Religious Practice and Social Class in Cairo.

The First Wahhabi Movement, 1745-1811.

Organizational Aspects of Industrialization in Turkey.

The Governing Institutions Which Were Brought to Anatolia by the Mongols.

The Jews of 1 mir in the 17 th and 18 th Centuries.

A Study of ${ }^{C}$ Ubayd-i Zäkän $\bar{i}$ : Prose and Poetry.

Taha Husayn and the Classical Arabic Heritage.

Imitation and Interpretation in Islamic Law.

\section{Appointments and Promotions}

Malcolm Kerr - President, American University of Beirut.

Maurice M. Roumani-Director, J.R. Elyachar Center for Studies in Sephardi Heritage, Ben-Gurion $U$ of the Negev. 
Ergün özbüdün

Gary S. Sick

Irfan Shahid

- Visiting Professor, Columbia University.

- Research Assistant, Middle East Institute, Columbia University.

- Inaugural holder of the Sultanate of Oman Chair in Arabic and Islamic Literature, Georgetown U.

Lisa S. Anderson - Assistant Professor of Political Science, Harvard University.

Ross Brann

- Assistant Professor of Hebrew Language and Literature, NYU.

Ellen Ervin - Research Assistant Professor of Turkish Language and Literature, NYU.

Arsenio Martinez - Adjunct Associate Professor of Arabic, NYU.

Priscilla Soucek - Professor of Islamic Art, NYU.

Mansour Ajami - Assistant Professor of Arabic, Princeton U.

Walter Feldman - Assistant Professor of Turkish, Princeton U.

Frederick Donner - Associate Professor of Classical and Medieval Islamic History, University of Chicago.

Abdul-Karim Rafeq- Visiting Professor of Modern Arab History, University of Chicago.

John Perry

- Associate Professor of Persian, University of Chicago.

Robert Dankoff - Associate Professor of Turkish, University of Chicago.

Farouk Mustafa - Senior Lecturer in Arabic, University of Chicago.

Sajida S. Alvi - Associate Professor, University of Minnesota.

Rosalind Gwynne - Assistant Professor of Arabic, University of Tennessee.

Jere L. Bacharach- Full Professor, Department of History, University of Washington.

Robert J. Wenke - Associate Professor, University of Washington.

Naomi J. Williams-Assistant Professor of Political Science, Yale University.

Irene A. Bierman - Assistant Professor of Art History, UCLA.

\section{Fellowships and Grants A warded}

Aga Khan Program for Islamic Architecture, 1980-81 Harvard University/Massachusetts Institute of Technology

Doris B. Abousif [Cairo]

Partial support of study on Azbakiyya quarter in Egypt, 1468 to modern times.

American Committee for South Asian Art

Matching funds with NEH to support photo documentation of Islamic architecture in Bihar and Benghal.

Peter A. Andrews [London]

History of the tent in North Africa, Turkey, Iran, Arabia, and Central Asia.

Ülkü Bates [Hunter Coll lege, NY]

Research support for study on architecture of Ottoman Cairo.

Reinhard Goethert [MIT]

Grant for exhibition and catalogue of Hassan Fathy's work.

S. Gulzar Haider [Ottawa]

To complete study of Islamic architecture of the Lower Sind. 